\title{
Prognostic Significance of EGFR Gene Amplification and Overexpression in Diffuse Astrocytomas-A Literature Study
}

\author{
Kristoffer Winje Hagen ${ }^{1}$, Sverre Helge Torp ${ }^{1,2 \#}$ \\ ${ }^{1}$ Department of Laboratory Medicine, Children's and Women’s Health, Faculty of Medicine, Norwegian University of Science and \\ Technology (NTNU), Trondheim University Hospital, Trondheim, Norway; ${ }^{2}$ Department of Pathology and Medical Genetics, St. \\ Olav's Hospital, Trondheim, Norway. \\ Email: "sverre.torp@ntnu.no
}

Received May $7^{\text {th }}$, 2012; revised June $8^{\text {th }}$, 2012; accepted June $15^{\text {th }}, 2012$

\begin{abstract}
Epidermal growth factor receptor (EGFR) has been shown to play an important role in the malignant progression of diffuse astrocytomas. Numerous studies have investigated the clinical significance of overexpression and amplification of the EGFR gene in these tumours with ambiguous results. The aim of this study was therefore to review the literature to get the current prognostic and diagnostic status. The PubMed database was used to search for papers in English in the time period 1987-2010 using the following keywords: astrocytoma, glioma, c-erbB1, EGFR, glioblastoma, HER1 and prognosis. Other inclusion criteria were: 1) studies with more than 50 patients; 2) patient age over 18 years; 3) tumour grading according to the latest World Health Organization (WHO) classification (2007) and 4) EGFR overexpression assessed by immunohistochemistry. A total of 47 publications were included and several reported positive correlations between both EGFR gene amplification and overexpression with histological malignancy grade and survival. The results are, however, encumbered with elements of uncertainty involving for instance methodological diversities and small number of patients. Larger studies with standardized procedures are necessary to fully clarify the clinical role of EGFR in human astrocytomas.
\end{abstract}

Keywords: Brain Tumours; Diagnosis; erbB; Glioblastomas; Gliomas; Immunohistochemistry; HER; Receptor; Review; Survival

\section{Introduction}

Diffuse astrocytomas constitute the largest group of primary malignant human intracranial tumours. They are classified by the World Health Organization (WHO) into three histological malignancy grades: diffuse astrocytomas grade II, grade III (anaplastic astrocytomas) and grade IV (glioblastoma (GBM)), based on histopathological features such as cellular atypia, mitotic activity, necrosis and microvascular proliferation. Actually, grade II-IV astrocytomas can be regarded as a continuum along an axis of increasing malignancy. They have a considerable propensity to recur after surgery due to their infiltrative growth and to progress over time to more malignant forms with worse prognosis. Despite multimodal therapies, including surgical resection, radiotherapy and chemotherapy, less than half of the patients survive more than a year [1]. In each histological group, however, there are considerable differences in survival, partly due

\footnotetext{
${ }^{*}$ Conflict of Interest: Declared none.

${ }^{\#}$ Corresponding author.
}

to heterogeneous tumour tissue and suboptimal classification systems. The histopathological diagnosis of these tumours is challenging, and various immunohistological and molecular genetic approaches have been introduced to improve the diagnostic accuracy.

Activation of oncogenes and inactivation of tumour-suppressor genes have been shown to be influential on development and growth of human astrocytomas. In this context the epidermal growth factor receptor (EGFR) is central. It is linked to the malignant transformation of these tumours by gene amplification, overexpression, and mutated variants, where EGFRvIII is the most common [2]. EGFR is a $170-\mathrm{kDa}$ transmembrane tyrosine kinase receptor expressed in a variety of normal and malignant cells regulating critical cellular processes. When activated, EGFR triggers a number of signalling cascades via the Rasmitogen-activated protein kinase pathway and the phosphatidyl-inositol 3 kinase-protein kinase B (Akt) pathway, and thus behaves as a potent oncogene [3].

Amplification of the EGFR gene is a common genetic 
event in high-grade astrocytomas and occurs in about half of GBMs. It leads to overexpression at both the mRNA and protein levels, however, overexpression without this genetic event occurs as well [4,5]. Approximately $50 \%$ of GBMs with EGFR gene amplification also express EGFRvIII [6,7]. This is a mutated variant with truncated extracellular ligand-binding domain and is thus constitutively activated [8].

Overexpression of EGFR has proven to be a negative prognostic marker for multiple cancer types such as breast [9], bladder [10], oesophagus [11], cervix [12] and ovary [13]. Further, in carcinomas of the lung and colon EGFR-mediated molecular targeted therapy has been introduced [14]. In malignant gliomas, however, the prognostic and diagnostic role of EGFR has to date provided divergent results.

The aim of this study was therefore to survey the literature to get an updated collective status of EGFR's role in human astrocytomas with regard to diagnostic and prognostic aspects as well as to discuss some relevant methodological factors.

\section{Material and Methods}

The PubMed database was used to search for publications using the following keywords: glioma, astrocytoma, glioblastoma, c-erbB1, EGFR, HER1 and prognosis. Other inclusion criteria were: 1 ) studies with more than 50 patients; 2) diffuse astrocytomas grade II, II, and IV according to the latest WHO classification scheme [1]; 3) EGFR overexpression (assessed by immunohistochemistry); 4) EGFR gene amplification; 5) articles written in English and published in the time period 1987-2010 and 6 ) adult patients (age $>18$ years).

The following factors were recorded: number of patients, patient age, histological malignancy grade, pattern of EGFR expression (membranous and/or cytoplasmic), type of antibody (see Table 1: clone, monoclonal, polyclonal, epitope (external or internal EGFR domain)), EGFR gene dose and detection method (southern or slot blots, polymerase chain reactions, in situ hybridization), EGFR's clinical significance (relationship to prognosis (overall or progression free survival) or tumour grade), and statistical analysis applied (uni- or multivariate).

\section{Results}

A total number of 47 publications fulfilled the inclusion criteria, and the results are presented chronologically in Table 2. In Figure 1 a typical EGFR immunostaining of a high-grade astrocytoma is shown.

Twenty-five enrolled publications that had analyzed EGFR gene amplification in human astrocytomas, displayed an approximate percentage range in grade II-IV

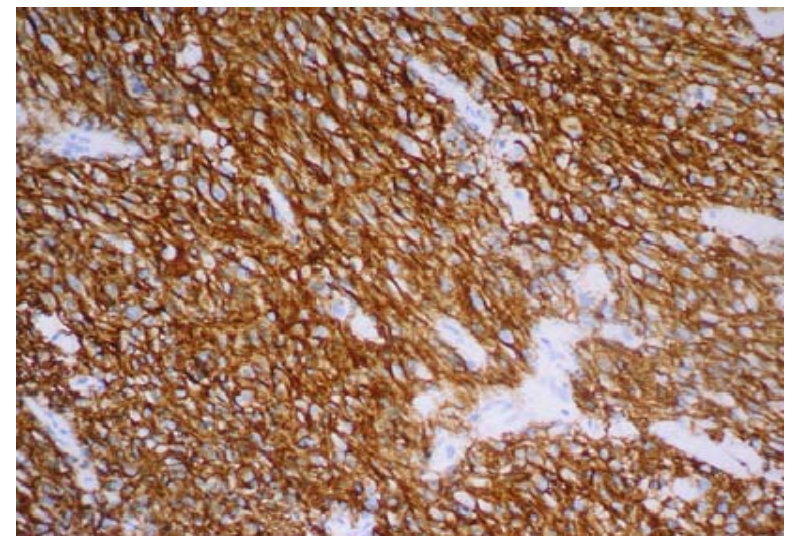

Figure. 1. Glioblastoma with strong immunoreactivity for EGFR (clone EGFR 113) (20× objective).

tumours of $0 \%-4 \%, 0 \%-33 \%$, and $34 \%-64 \%$, respectively. Six publications found that amplification correlated significantly to histological malignancy grade [1520] and seven found amplification to be a significant prognostic factor on overall survival [7,15,16,21-25]. Some studies reported amplification to be associated with poorer prognosis in the younger and better prognosis in the elderly [15,21,25].

Overexpression of EGFR was examined in 28 publications. The percentage of astrocytomas overexpressing EGFR was in the range of $6 \%-28 \%, 27 \%-70 \%$, and $22 \%-89 \%$, in grade II-IV tumours, respectively $[4,7$, $17,18,24,26-48]$. Nine studies investigated the association between degree of expression and tumour grade, and such a constellation was demonstrated in only three studies $[17,27,29]$. Several publications showed prognostic significance on overall or progression free survival $[7,24$, 26,29,31,34-37,45-48].

Studies on EGFRvIII immunostaining revealed positivity only in high-grade astrocytomas with a frequency up to approximately $14 \%$ and $45 \%$ in anaplastic astrocytomas and GBMs, respectively [6,7,25,32,49]. In GBMs this expression was highly dependent on gene amplification, whereas it occurred approximately similarly in anaplastic astrocytomas with and without this genetic event [25]. Relations to survival showed that in anaplastic astrocytomas EGFRvIII was a significant predictor of unfavourable survival, especially with increasing patient age $[6,25]$. Among patients with GBMs, EGFRvIII positivity did not display any association with survival. In combination with EGFR gene amplification, however, other genetic subtypes, and patients surviving one year or more, it was a negative prognostic indicator $[7,25,32,49]$.

\section{Discussion}

EGFR gene rearrangements and overexpression in human astrocytomas have been in the focus of scientists for 
Table 1. Survey of antibodies used in the reviewed studies.

\begin{tabular}{|c|c|c|c|c|}
\hline & Poly-/monoclonal & Intracellular domain & Extracellular domain & Publications \\
\hline Clone E30 & Monoclonal & & $\mathrm{X}$ & {$[17,38,42,45]$} \\
\hline Clone F4 & Monoclonal & $\mathrm{X}$ & & {$[35,48]$} \\
\hline Clone 113 & Monoclonal & & $\mathrm{X}$ & {$[7,28,34]$} \\
\hline Clone $\mathrm{Ab}-4$ & Polyclonal & & $\mathrm{X}$ & {$[27,44]$} \\
\hline Clone 528 & Monoclonal & & $\mathrm{X}$ & {$[25,26,32,37]$} \\
\hline Clone 25 & Monoclonal & $\mathrm{X}$ & & {$[4,7]$} \\
\hline Clone H11 & Monoclonal & & $\mathrm{X}$ & {$[43,45,46]$} \\
\hline EGFR-Ab-10 (clone 111.6) & Monoclonal & & $\mathrm{X}$ & [41] \\
\hline Clone 31G7 & Monoclonal & & $\mathrm{X}$ & [30] \\
\hline Clone 3C6 & Monoclonal & & $\mathrm{X}$ & [33] \\
\hline
\end{tabular}

Table 2. Survey of findings in the reviewed publications.

\begin{tabular}{|c|c|c|c|c|}
\hline Publications & No. of cases & EGFR analysis & Statistical analysis & Findings and comment \\
\hline$[50]$ & 54 & Amplification & $\begin{array}{l}\text { UVA } \\
\text { MVA }\end{array}$ & $\begin{array}{l}\text { No prognostic significance on overall survival. } \\
\text { No significant correlation between amplification and } \\
\text { histological malignancy grade. }\end{array}$ \\
\hline [39] & 88 & Overexpression & NS & No prognostic significance on overall survival. \\
\hline$[42]$ & 72 & Overexpression & UVA & $\begin{array}{l}\text { No prognostic significance on overall survival. } \\
\text { No significant correlation between overexpression and } \\
\text { histological malignancy grade. }\end{array}$ \\
\hline$[18]$ & 75 & $\begin{array}{l}\text { Amplification and } \\
\text { Overexpression }\end{array}$ & UVA & $\begin{array}{l}\text { No prognostic significance on progression free survival } \\
\text { Significant correlation between amplification and histo- } \\
\text { logical malignancy grade. }\end{array}$ \\
\hline$[17]$ & $\begin{array}{l}\text { Exp.: } 115 \\
\text { Amp.: } 97\end{array}$ & $\begin{array}{l}\text { Amplification and } \\
\text { overexpression }\end{array}$ & $\begin{array}{l}\text { UVA } \\
\text { MVA }\end{array}$ & $\begin{array}{l}\text { No prognostic significance on overall survival. } \\
\text { Significant correlation between amplification/ } \\
\text { overexpression and histological malignancy grade. }\end{array}$ \\
\hline$[48]$ & 71 & Overexpression & $\begin{array}{l}\text { UVA } \\
\text { MVA }\end{array}$ & $\begin{array}{l}\text { Significant negative prognostic factor on overall survival } \\
\text { and progression free survival in UVA and MVA with } \\
\text { EGFR as a continuous variable. } \\
\text { No significant correlation between overexpression and } \\
\text { histological malignancy grade. }\end{array}$ \\
\hline$[34]$ & 51 & Overexpression & $\begin{array}{l}\text { UVA } \\
\text { MVA }\end{array}$ & $\begin{array}{l}\text { Significant negative prognosis on progression free sur- } \\
\text { vival. } \\
\text { No significant correlation between overexpression and } \\
\text { histological malignancy grade. }\end{array}$ \\
\hline$[27]$ & 107 & Overexpression & UVA & $\begin{array}{l}\text { No prognostic significance on overall survival. } \\
\text { Significant correlation between overexpression and } \\
\text { histological malignancy grade. }\end{array}$ \\
\hline$[28]$ & 63 & Overexpression & $\begin{array}{l}\text { UVA } \\
\text { MVA }\end{array}$ & $\begin{array}{l}\text { No prognostic significance on progression free survival } \\
\text { and overall survival. }\end{array}$ \\
\hline$[31]$ & 79 & Overexpression & MVA & $\begin{array}{l}\text { Significant predictor of shorter overall survival. } \\
\text { Trend towards correlation between overexpression and } \\
\text { histological malignancy grade. }\end{array}$ \\
\hline$[54]$ & 75 & Amplification & UVA & No prognostic significance on overall survival. \\
\hline$[38]$ & 80 & Overexpression & UVA & No prognostic significance on overall survival. \\
\hline$[19]$ & 93 & Amplification & $\begin{array}{l}\text { UVA } \\
\text { MVA }\end{array}$ & $\begin{array}{l}\text { No prognostic significance on overall survival. } \\
\text { Significant correlation between amplification and histo- } \\
\text { logical malignancy grade. }\end{array}$ \\
\hline
\end{tabular}




\section{Continued}

\begin{tabular}{|c|c|c|c|c|}
\hline [36] & 168 & Overexpression & $\begin{array}{l}\text { UVA } \\
\text { MVA }\end{array}$ & Statistical significant decreased overall survival. \\
\hline [29] & 81 & Overexpression & $\begin{array}{l}\text { UVA } \\
\text { MVA }\end{array}$ & $\begin{array}{l}\text { Statistical significant reduced overall survival. } \\
\text { Significant correlation between overexpression and } \\
\text { histological malignancy grade. }\end{array}$ \\
\hline [26] & 110 & Overexpression & $\begin{array}{l}\text { UVA } \\
\text { MVA }\end{array}$ & $\begin{array}{l}\text { Significant improved prognosis for patients } \geq 55 \text { years, } \\
\text { trend toward worse overall survival for patients }<55 \\
\text { years in UVA. } \\
\text { Significant negative prognostic factor for p53wild-type- } \\
\text { negative cases }<55 \text { years. }\end{array}$ \\
\hline [15] & 174 & Amplification & $\begin{array}{l}\text { UVA } \\
\text { MVA }\end{array}$ & $\begin{array}{l}\text { Trend towards shorter overall survival for AA in UVA. } \\
\text { Significant better prognosis when age } \geq 60 \text { in MVA. } \\
\text { Significant correlation between amplification and } \\
\text { histological malignancy grade. }\end{array}$ \\
\hline [35] & 302 & Overexpression & $\begin{array}{l}\text { UVA } \\
\text { MVA }\end{array}$ & Significant negative prognostic factor on overall survival. \\
\hline [37] & 59 & Overexpression & $\begin{array}{l}\text { UVA } \\
\text { MVA }\end{array}$ & $\begin{array}{l}\text { Significant shorter overall survival in overall population } \\
\text { and high-grade astrocytomas in UVA. } \\
\text { No significant correlation between overexpression and } \\
\text { histological malignancy grade. }\end{array}$ \\
\hline [53] & 129 & Amplification & $\begin{array}{l}\text { UVA } \\
\text { MVA }\end{array}$ & No prognostic significance on overall survival. \\
\hline [7] & 87 & $\begin{array}{l}\text { Amplification, } \\
\text { overexpression and } \\
\text { EGFRvIII expression }\end{array}$ & $\begin{array}{l}\text { UVA } \\
\text { MVA }\end{array}$ & $\begin{array}{l}\text { Significant unfavorable predictor on overall survival for } \\
\text { amplification in UVA/MVA, overexpression in UVA. } \\
\text { EGFRvIII showed a trend towards shorter overall } \\
\text { survival in UVA and significant shorter survival for } \\
\text { EGFRvIII with amplification in MVA. }\end{array}$ \\
\hline [43] & 143 & Overexpression & $\begin{array}{l}\text { UVA } \\
\text { MVA }\end{array}$ & No prognostic significance on overall survival. \\
\hline [44] & 95 & Overexpression & $\begin{array}{l}\text { UVA } \\
\text { MVA }\end{array}$ & No prognostic significance on overall survival. \\
\hline [20] & 87 & Amplification & $\begin{array}{l}\text { UVA } \\
\text { MVA }\end{array}$ & $\begin{array}{l}\text { No prognostic significance on overall survival. } \\
\text { Significant correlation between amplification and tumor } \\
\text { grade. }\end{array}$ \\
\hline [21] & 133 & Amplification & $\begin{array}{l}\text { UVA } \\
\text { MVA }\end{array}$ & $\begin{array}{l}\text { Significant negative prognostic factor on overall survival } \\
\text { when patient }<46 \text { years. } \\
\text { Significant positive prognostic marker on overall } \\
\text { survival when patient }>46 \text { years. }\end{array}$ \\
\hline [25] & 168 & $\begin{array}{l}\text { Amplification and } \\
\text { EGFRvIII expression }\end{array}$ & $\begin{array}{l}\text { UVA } \\
\text { MVA }\end{array}$ & $\begin{array}{l}\text { AA: amp.: significant negative prognostic factor on } \\
\text { overall survival in UVA. } \\
\text { AA: EGFRvIII: Significant negative prognostic factor } \\
\text { on overall survival in UVA. } \\
\text { No prognostic significance on overall survival with amp } \\
\text { or EGFRvIII for GBM. }\end{array}$ \\
\hline [55] & 715 & Amplification & $\begin{array}{l}\text { UVA } \\
\text { MVA }\end{array}$ & No prognostic significance on overall survival. \\
\hline [41] & 58 & Overexpression & $\begin{array}{l}\text { UVA } \\
\text { MVA }\end{array}$ & No prognostic significance on progression free survival. \\
\hline [46] & 103 & Overexpression & $\begin{array}{l}\text { UVA } \\
\text { MVA }\end{array}$ & $\begin{array}{l}\text { Significant negative prognostic factor on overall survival } \\
\text { for AII. } \\
\text { No significant correlation between overexpression and } \\
\text { histological malignancy grade. }\end{array}$ \\
\hline [30] & 155 & Overexpression & $\begin{array}{l}\text { UVA } \\
\text { MVA }\end{array}$ & $\begin{array}{l}\text { No prognostic significance on overall and progression } \\
\text { free survival. }\end{array}$ \\
\hline [32] & 196 & $\begin{array}{l}\text { Overexpression and } \\
\text { EGFR vIII expression }\end{array}$ & $\begin{array}{l}\text { UVA } \\
\text { MVA }\end{array}$ & $\begin{array}{l}\text { No prognostic significance on overall survival. } \\
\text { EGFRvIII: significant negative prognostic factor for } \\
\text { patients who survive } \geq 1 \text { year. }\end{array}$ \\
\hline [22] & 189 & Amplification & $\begin{array}{l}\text { UVA } \\
\text { MVA }\end{array}$ & $\begin{array}{l}\text { Significant unfavorable prognostic factor on overall } \\
\text { survival in UVA. }\end{array}$ \\
\hline
\end{tabular}




\begin{tabular}{|c|c|c|c|c|}
\hline$[6]$ & 221 & $\begin{array}{l}\text { Amplification and } \\
\text { EGFR vIII expression }\end{array}$ & $\begin{array}{l}\text { UVA } \\
\text { MVA }\end{array}$ & $\begin{array}{l}\text { Trend towards decreased postoperative survival with } \\
\text { amp or EGFRvIII for AA in UVA. }\end{array}$ \\
\hline [56] & 107 & Amplification & $\begin{array}{l}\text { UVA } \\
\text { MVA }\end{array}$ & No prognostic significance on overall survival. \\
\hline [23] & 220 & Amplification & $\begin{array}{l}\text { UVA } \\
\text { MVA }\end{array}$ & $\begin{array}{l}\text { Significant positive prognostic factor on overall survival } \\
\text { in MVA (adjusted for age). }\end{array}$ \\
\hline [16] & 338 & Amplification & $\begin{array}{l}\text { UVA } \\
\text { MVA }\end{array}$ & $\begin{array}{l}\text { Significant worse overall survival for AA in UVA. } \\
\text { Significant correlation between amplification and } \\
\text { histological malignancy grade. }\end{array}$ \\
\hline [47] & 595 & $\begin{array}{l}\text { Amplification and } \\
\text { overexpression }\end{array}$ & $\begin{array}{l}\text { UVA } \\
\text { MVA }\end{array}$ & $\begin{array}{l}\text { AA: exp.: Significant negative prognostic factor on } \\
\text { overall survival in UVA. } \\
\text { AA: amp.: Trend towards negative prognostic factor on } \\
\text { overall survival in UVA. } \\
\text { GBM exp.: trend to positive prognostic factor on overall } \\
\text { survival in UVA and MVA. }\end{array}$ \\
\hline [49] & 649 & EGFRvIII expression & $\begin{array}{l}\text { UVA } \\
\text { MVA }\end{array}$ & $\begin{array}{l}\text { EGFRvIII negative GBMs together with genetic changes } \\
\text { implied poorer overall survival. }\end{array}$ \\
\hline [40] & 51 & Overexpression & MVA & No prognostic significance on overall survival. \\
\hline [33] & 99 & Overexpression & UVA & No prognostic significance on postoperative survival. \\
\hline [24] & 194 & $\begin{array}{l}\text { Amplification and } \\
\text { overexpression }\end{array}$ & $\begin{array}{l}\text { UVA } \\
\text { MVA }\end{array}$ & $\begin{array}{l}\text { Significant poorer overall survival in UVA when EGFR } \\
\text { were amplified/overexpressed and p53-immunopositive. }\end{array}$ \\
\hline [45] & 54 & Overexpression & $\begin{array}{l}\text { UVA } \\
\text { MVA }\end{array}$ & $\begin{array}{l}\text { Significant negative prognostic factor on overall survival } \\
\text { in MVA. }\end{array}$ \\
\hline [57] & 301 & Amplification & $\begin{array}{l}\text { UVA } \\
\text { MVA }\end{array}$ & $\begin{array}{l}\text { No prognostic significance on overall or progression } \\
\text { free survival. }\end{array}$ \\
\hline [52] & 112 & Amplification & $\begin{array}{l}\text { UVA } \\
\text { MVA }\end{array}$ & $\begin{array}{l}\text { No prognostic significance on overall or progression } \\
\text { free survival. }\end{array}$ \\
\hline [4] & 99 & $\begin{array}{l}\text { Amplification and } \\
\text { overexpression }\end{array}$ & $\begin{array}{l}\text { UVA } \\
\text { MVA }\end{array}$ & $\begin{array}{l}\text { Amplification showed a trend towards worse overall } \\
\text { survival in MVA, when analysis was done with FISH. }\end{array}$ \\
\hline [71] & 149 & Amplification & MVA & No prognostic significance on overall survival. \\
\hline
\end{tabular}

Abbreviations: UVA, univariate analysis; MVA, multivariate analysis; Amp., EGFR amplification; Exp., EGFR overexpression; GBM, glioblastoma multiforme; AA, anaplastic astrocytoma; AII, grade II astrocytoma.

several years because of the receptor's pivotal role in gliomagenesis, and, accordingly, for potential use in prognostic, diagnostic and therapeutic aspects. Still, the clinical significance is controversial. We therefore decided to survey relevant literature to get an overview of the current status of EGFR's clinical role as well as to discuss some sources of errors. In general, frequent overexpression and amplification of the EGFR gene occur predominantly in high-grade astrocytomas, whereas the clinical aspects still appear unclarified.

Studies have shown that the frequency of EGFR gene amplification increases significantly with increasing tumour grade. In grade II astrocytomas amplification is a rare event and was only found in one study with a frequency of 4\% [16]. Up to one third of anaplastic astrocytomas were shown to harbour an amplified EGFR gene [6,15-17,19,25,50,51], whereas in GBMs it was encountered in about $60 \%$ of the cases [4,6,7,15-19,21-25,47, 50-57]. These results highlight the significance of amplification as a central process in the molecular pathway not only for primary GBMs but for secondary GBMs as well.
The high frequency of EGFR amplification in GBMs can be used in the distinction between small cell GBMs and anaplastic oligodendrogliomas [58].

EGFR gene amplification was detected by different methods with varying sensitivity, thus providing possible variations in the frequency of this phenomenon. For instance, one study investigated the association between amplification determined by FISH and PCR, and found amplification in $47.4 \%$ and $63.6 \%$ of the tumour samples, respectively [4]. This clearly illustrates the need for standardization of such methods. Additionally, the wellknown heterogeneity of glioblastoma tissue may be influential on tumour sampling and thus explain varying results.

Conflicting findings exist with regard to the association between prognosis and EGFR gene amplification. Intriguingly, it seems to be a positive relationship between the prognostic value of amplification and age. This is illustrated by the fact that older GBM patients with amplified gene have significantly increased survival compared with younger age groups [7,15,21-23,25]. Further, amplification has been found to be significantly more 
frequent in GBMs in older patients than in younger ones $[16,22,59]$. These observations may reflect age-related different molecular pathways in gliomagenesis [21]. Another explanation could be that the astrocytomas with EGFR gene amplification in younger patients are a subgroup of astrocytomas with a more aggressive biology. Some studies also found that amplification conferred a negative influence on survival in patients with anaplastic astrocytomas $[6,16,25,47]$. This may indicate a subgroup with a more aggressive behaviour. One cannot, however, exclude that some of these tumours represent small-cell GBMs.

Regarding EGFR overexpression, all studies demonstrated an increasing frequency of overexpression with increasing tumour grade. Noteworthy is the use of different antibodies with immunoreactivity against either the external or the internal domain of the receptor. This makes comparison of studies difficult. We have for instance found that the latter unveiled higher number of EGFR immunoreactive astrocytomas. It is therefore possible that the external domain is more vulnerable to fixation or tissue processing than the internal one $[60,61]$. Since most studies used antibodies directed against the external domain, it may be that EGFR expression in astrocytomas is more abundant than expected. Actually, in previous studies using binding assays with biotinylated EGF on glioma tissue, we found that this technique was superior in detecting EGFR overexpression than antibodies [62]. Hence, due to methodological heterogeneity of determination of this receptor protein in tumour samples, there is a need for standardization. Promising is the introduction of EGFR immunohistochemical kits, such as the commercial kits for c-erbB2/HER2 testing in breast cancer.

Studies have shown that reactive astrocytes express EGFR, whereas normal astrocytes do not $[62,63]$. This is demonstrated by an upregulation of EGFR in astrocytes after brain injury with release of epidermal growth factor [64]. Thus, EGFR serves as a marker of astrocyte activation. For this reason EGFR immunoreactivity cannot be used uncritically to distinguish between reactive and neoplastic astrocytes. A recent study has, however, reported a stronger immunological EGFR reactivity in the latter [65].

Most studies have showed that overexpression of EGFR is a result of gene amplification [4,7,17,24,47]. There are, however, reports in which overexpression occurs in the absence of this genetic event $[16,17,66]$. In these cases, overexpression may be a result of changes in transcription, protein stability and/or protein modification unrelated to amplification.

As only 13 out of 28 studies found EGFR overexpression to be a significant prognostic factor, its role in this context is debatable. One study found overexpression to be significantly associated with better prognosis in older patients and a trend toward worse overall survival amongst the younger [26]. Another study showed a significant shorter overall survival for patients with overexpression and p53 mutations [24]. In respect to analysis using immunohistochemistry, it can be argued that overexpression used as a continuous variable, as opposed to dichotomous, can be more useful to predict outcome in EGFR positive patients [48].

The mutant EGFRvIII has gained much interest because of its selective expression on neoplastic astrocytes, and thus represents a promising goal in molecular targeted therapy $[67,68]$. It is detected immunohistochemically predominantly in anaplastic astrocytomas and GBMs, most frequent in the latter $[6,7,25,32,49]$. Its expression is tightly linked to EGFR gene amplification with some exceptions $[7,25]$. Furthermore, the antibodies used may also influence the results of EGFRvIII expression $[61,69,70]$. Concerning prognosis, the data appear somewhat complex due to additional genetic and clinical factors. For instance, its expression seems only to have prognostic value in patients with anaplastic astrocytomas, and especially with increasing patient age $[6,25]$. In GBMs EGFRvIII expression combined with molecular genetic findings, such as EGFR gene amplification, coexpression of PTEN (phosphatase and tensin homologue deleted in chromosome 10) tumour-suppressor protein and activation of the AKT/MAPK pathways and YKL-40, was shown to be associated with poorer prognosis $[7,49$, 68].

This review has no intention to pose as a meta-analysis or to declare the definite clinical role of EGFR in human astrocytomas, just to present an update of the current status. There are several limitations of such a study, including its retrospective issue, small series of patients and various detection systems making comparisons problematic. In any case, the literature is conflicting regarding this receptor protein as a biological marker, pointing to the fact that it does not behave as an independent marker in the gliomagenesis. Still, one cannot rule out EGFR as a promising and potential tool in various clinical aspects as far as astrocytomas are concerned. Larger studies are, however, necessary to predict the clinical role of EGFR in these tumours, and not least, to establish feasible, robust and reproducible detections systems for overexpression and amplification of the EGFR gene in astrocytic tumour tissue.

\section{REFERENCES}

[1] D. N. Louis, H. Ohgaki, O. D. Wiestler and W. K. Cavenee, "WHO Classification of Tumours of the Central 
Nervous System," $4^{\text {th }} 7$ Edition, IARC, Lyon, 2007.

[2] T. Mitsudomi and Y. Yatabe, "Epidermal Growth Factor Receptor in Relation to Tumor Development: EGFR Gene and Cancer,” FEBS Journal, Vol. 277, No. 2, 2010, pp. 301-308. doi:10.1111/j.1742-4658.2009.07448.x

[3] M. A. Lemmon and J. Schlessinger, "Cell Signaling by Receptor Tyrosine Kinases,” Cell, Vol. 141, No. 7, 2010, pp. 1117-1134. doi:10.1016/j.cell.2010.06.011

[4] B. Coulibaly, I. Nanni, B. Quilichini, J. Gaudart, P. Metellus, F. Fina, C. Boucard, O. Chinot, L. Ouafik and D. Figarella-Branger, "Epidermal Growth Factor Receptor in Glioblastomas: Correlation between Gene Copy Number and Protein Expression," Human Pathology, Vol. 41, No. 6, 2010, pp. 815-823.

doi:10.1016/j.humpath.2009.09.020

[5] J. Schlegel, A. Merdes, G. Stumm, F. K. Albert, M. Forsting, N. Hynes and M. Kiessling, “Amplification of the Epidermal-Growth-Factor-Receptor Gene Correlates with Different Growth Behaviour in Human Glioblastoma," International Journal of Cancer, Vol. 56, No. 1, 1994, pp. 72-77. doi:10.1002/ijc.2910560114

[6] L. Liu, L. M. Backlund, B. R. Nilsson, D. Grander, K. Ichimura, H. M. Goike and V. P. Collins, "Clinical Significance of EGFR Amplification and the Aberrant EGFRvIII Transcript in Conventionally Treated Astrocytic Gliomas,” Journal of Molecular Medicine, Vol. 83, No. 11, 2005, pp. 917-926. doi:10.1007/s00109-005-0700-2

[7] N. Shinojima, K. Tada, S. Shiraishi, T. Kamiryo, M. Kochi, H. Nakamura, K. Makino, H. Saya, H. Hirano, J. Kuratsu, K. Oka, Y. Ishimaru and Y. Ushio, "Prognostic Value of Epidermal Growth Factor Receptor in Patients with Glioblastoma Multiforme," Cancer Research, Vol. 63, No. 20, 2003, pp. 6962-6970.

[8] H. S. Huang, M. Nagane, C. K. Klingbeil, H. Lin, R. Nishikawa, X. D. Ji, C. M. Huang, G. N. Gill, H. S. Wiley and W. K. Cavenee, "The Enhanced Tumorigenic Activity of a Mutant Epidermal Growth Factor Receptor Common in Human Cancers Is Mediated by Threshold Levels of Constitutive Tyrosine Phosphorylation and Unattenuated Signaling,” Journal of Biological Chemistry, Vol. 272, No. 5, 1997, pp. 2927-2935.

doi:10.1074/jbc.272.5.2927

[9] J. R. C. Sainsbury, J. R. Farndon, G. K. Needham, A. J. Malcolm and A. L. Harris, "Epidermal-Growth-Factor Receptor Status as Predictor of Early Recurrence of and Death from Breast-Cancer,” Lancet, Vol. 1, No. 8547, 1987, pp. 1398-1402.

[10] D. E. Neal, C. Marsh, M. K. Bennett, P. D. Abel, R. R. Hall, J. R. Sainsbury and A. L. Harris, "EpidermalGrowth-Factor Receptors in Human Bladder Cancer: Comparison of Invasive and Superficial Tumours," Lancet, Vol. 1, No. 8425, 1985, pp. 366-368. doi:10.1016/S0140-6736(85)91386-8

[11] S. Ozawa, M. Ueda, N. Ando, N. Shimizu and O. Abe, "Prognostic Significance of Epidermal Growth Factor Receptor in Esophageal Squamous Cell Carcinomas," Cancer, Vol. 63, No. 11, 1989, pp. 2169-2173.
doi:10.1002/1097-0142(19890601)63:11<2169::AID-CN CR2820631117>3.0.CO;2-W

[12] D. Pfeiffer, B. Stellwag, A. Pfeiffer, P. Borlinghaus, W. Meier and P. Scheidel, "Clinical Implications of the Epidermal Growth Factor Receptor in the Squamous Cell Carcinoma of the Uterine Cervix,” Gynecologic Oncology, Vol. 33, No. 2, 1989, pp. 146-150. doi:10.1016/0090-8258(89)90540-4

[13] T. Bauknecht, M. Koler, I. Janz and A. Pfleiderer, “The Occurrence of Epidermal Growth Factor Receptors and the Characterization of EGF-Like Factors in Human Ovarian, Endometrial, Cervical and Breast Cancer. EGF Receptors and Factors in Gynecological Carcinomas," Journal of Cancer Research and Clinical Oncology, Vol. 115, No. 2, 1989, pp. 193-199. doi:10.1007/BF00397923

[14] M. Van den Eynde, J. F. Baurain, F. Mazzeo and J. P. Machiels, "Epidermal Growth Factor Receptor Targeted Therapies for Solid Tumours,” Acta Clinica Belgica, Vol. 66, No. 1, 2011, pp. 10-17.

[15] J. S. Smith, I. Tachibana, S. M. Passe, B. K. Huntley, T. J. Borell, N. Iturria, J. R. O’Fallon, P. L. Schaefer, B. W. Scheithauer, C. D. James, J. C. Buckner and R. B. Jenkins, "PTEN Mutation, EGFR Amplification, and Outcome in Patients with Anaplastic Astrocytoma and Glioblastoma Multiforme," Journal of the National Cancer Institute, Vol. 93, No. 16, 2001, pp. 1246-1256. doi:10.1093/jnci/93.16.1246

[16] S. Järvelä, H. Helin, J. Haapasalo, T. Järvelä, T. T. Junttila, K. Elenius, M. Tanner, H. Haapasalo and J. Isola, "Amplification of the Epidermal Growth Factor Receptor in Astrocytic Tumours by Chromogenic in Situ Hybridization: Association with Clinicopathological Features and Patient Survival," Neuropathology and Applied Neurobiology, Vol. 32, No. 4, 2006, pp. 441-450. doi:10.1111/j.1365-2990.2006.00758.x

[17] A. Waha, A. Baumann, H. K. Wolf, R. Fimmers, J. Neumann, D. Kindermann, K. Astrahantseff, I. Blumcke, A. von Deimling and U. Schlegel, "Lack of Prognostic Relevance of Alterations in the Epidermal Growth Factor Receptor-Transforming Growth Factor-Alpha Pathway in Human Astrocytic Gliomas,” Journal of Neurosurgery, Vol. 85, No. 4, 1996, pp. 634-641. doi:10.3171/jns.1996.85.4.0634

[18] U. Diedrich, J. Lucius, E. Baron, J. Behnke, B. Pabst and B. Zoll, "Distribution of Epidermal Growth Factor Receptor Gene Amplification in Brain Tumours and Correlation to Prognosis,” Journal of Neurology, Vol. 242, No. 10, 1995, pp. 683-688. doi:10.1007/BF00866920

[19] J. J. Olson, D. Barnett, J. Yang, R. Assietti, G. Cotsonis and C. D. James, "Gene Amplification as a Prognostic Factor in Primary Brain Tumors,” Clinical Cancer Research, Vol. 4, No. 1, 1998, pp. 215-222.

[20] Y. H. Zhou, F. Tan, K. R. Hess and W. K. Yung, "The Expression of PAX6, PTEN, Vascular Endothelial Growth Factor, and Epidermal Growth Factor Receptor in Gliomas: Relationship to Tumor Grade and Survival," Clinical Cancer Research, Vol. 9, No. 9, 2003, pp. 33693375 . 
[21] T. T. Batchelor, R. A. Betensky, J. M. Esposito, L. D. Pham, M. V. Dorfman, N. Piscatelli, S. Jhung, D. Rhee and D. N. Louis, "Age-Dependent Prognostic Effects of Genetic Alterations in Glioblastoma,” Clinical Cancer Research, Vol. 10, No. 1, 2004, pp. 228-233. doi:10.1158/1078-0432.CCR-0841-3

[22] A. Korshunov, R. Sycheva and A. Golanov, "The Prognostic Relevance of Molecular Alterations in Glioblastomas for Patients Age < 50 Years,” Cancer, Vol. 104, No. 4, 2005, pp. 825-832. doi:10.1002/cncr.21221

[23] C. Houillier, J. Lejeune, A. Benouaich-Amiel, F. LaigleDonadey, E. Criniere, K. Mokhtari, J. Thillet, J. Y. Delattre, K. Hoang-Xuan and M. Sanson, "Prognostic Impact of Molecular Markers in a Series of 220 Primary Glioblastomas," Cancer, Vol. 106, No. 10, 2006, pp. 22182223. doi:10.1002/cncr.21819

[24] Y. Ruano, T. Ribalta, A. R. de Lope, Y. Campos-Martin, C. Fiano, E. Perez-Magan, J. L. Hernandez-Moneo, M. Mollejo and B. Melendez, "Worse Outcome in Primary Glioblastoma Multiforme with Concurrent Epidermal Growth Factor Receptor and p53 Alteration,” American Journal of Clinical Pathology, Vol. 131, No. 2, 2009, pp. 257-263. doi:10.1309/AJCP64YBDVCTIRWV

[25] K. D. Aldape, K. Ballman, A. Furth, J. C. Buckner, C. Giannini, P. C. Burger, B. W. Scheithauer, R. B. Jenkins and C. D. James, "Immunohistochemical Detection of EGFRvIII in High Malignancy Grade Astrocytomas and Evaluation of Prognostic Significance,” Journal of Neuropathology and Experimental Neurology, Vol. 63, No. 7, 2004, pp. 700-707.

[26] M. L. Simmons, K. R. Lamborn, M. Takahashi, P. Chen, M. A. Israel, M. S. Berger, T. Godfrey, J. Nigro, M. Prados, S. Chang, F. G. Barker II and K. Aldape, "Analysis of Complex Relationships between Age, p53, Epidermal Growth Factor Receptor, and Survival in Glioblastoma Patients," Cancer Research, Vol. 61, No. 3, 2001, pp. 1122-1128.

[27] N. G. Rainov, K. U. Dobberstein, H. Bahn, H. J. Holzhausen, C. Lautenschlager, V. Heidecke and W. Burkert, "Prognostic Factors in Malignant Glioma: Influence of the Overexpression of Oncogene and Tumor-Suppressor Gene Products On Survival,” Journal of Neuro-Oncology, Vol. 35, No. 1, 1997, pp. 13-28. doi:10.1023/A:1005841520514

[28] C. Bouvier-Labit, O. Chinot, C. Ochi, D. Gambarelli, H. Dufour and D. Figarella-Branger, "Prognostic Significance of Ki67, p53 and Epidermal Growth Factor Receptor Immunostaining in Human Glioblastomas,” Neuropathology and Applied Neurobiology, Vol. 24, No. 5, 1998, pp. 381-388. doi:10.1046/j.1365-2990.1998.00137.x

[29] A. Chakravarti, M. A. Delaney, E. Noll, P. M. Black, J. S. Loeffler, A. Muzikansky and N. J. Dyson, "Prognostic and Pathologic Significance of Quantitative Protein Expression Profiling in Human Gliomas," Clinical Cancer Research, Vol. 7, No. 8, 2001, pp. 2387-2395.

[30] A. Chakravarti, W. Seiferheld, X. Tu, H. Wang, H. Z. Zhang, K. K. Ang, E. Hammond, W. Curran Jr. and M. Mehta, "Immunohistochemically Determined Total Epi- dermal Growth Factor Receptor Levels Not of Prognostic Value in Newly Diagnosed Glioblastoma Multiforme: Report from the Radiation Therapy Oncology Group," International Journal of Radiation Oncology, Biology, Physics, Vol. 62, No. 2, 2005, pp. 318-327. doi:10.1016/j.ijrobp.2004.10.037

[31] M. C. Etienne, J. L. Formento, C. Lebrun-Frenay, J. Gioanni, M. Chatel, P. Paquis, C. Bernard, A. Courdi, R. J. Bensadoun, J. P. Pignol, M. Francoual, P. Grellier, M. Frenay and G. Milano, "Epidermal Growth Factor Receptor and Labeling Index Are Independent Prognostic Factors in Glial Tumor Outcome," Clinical Cancer Research, Vol. 4, No. 10, 1998, pp. 2383-2390.

[32] A. B. Heimberger, R. Hlatky, D. Suki, D. Yang, J. Weinberg, M. Gilbert, R. Sawaya and K. Aldape, "Prognostic Effect of Epidermal Growth Factor Receptor and EGFRvIII in Glioblastoma Multiforme Patients,” Clinical Cancer Research, Vol. 11, No. 4, 2005, pp. 1462-1466. doi:10.1158/1078-0432.CCR-04-1737

[33] M. Kogiku, I. Ohsawa, K. Matsumoto, Y. Sugisaki, H. Takahashi, A. Teramoto and S. Ohta, "Prognosis of Glioma Patients by Combined Immunostaining for Survivin, Ki-67 and Epidermal Growth Factor Receptor," Journal of Clinical Neuroscience, Vol. 15, No. 11, 2008, pp. 1198-1203. doi:10.1016/j.jocn.2007.11.012

[34] P. Korkolopoulou, P. Christodoulou, K. Kouzelis, M. Hadjiyannakis, A. Priftis, G. Stamoulis, A. Seretis and E. Thomas-Tsagli, "MDM2 and p53 Expression in Gliomas: A Multivariate Survival Analysis Including Proliferation Markers and Epidermal Growth Factor Receptor,” British Journal of Cancer, Vol. 75, No. 9, 1997, pp. 1269-1278. doi:10.1038/bjc.1997.216

[35] A. Korshunov, A. Golanov and R. Sycheva, "Immunohistochemical Markers for Prognosis of Cerebral Glioblastomas,” Journal of Neuro-Oncology, Vol. 58, No. 3, 2002, pp. 217-236. doi:10.1023/A:1016218117251

[36] A. Korshunov, A. Golanov, R. Sycheva and I. Pronin, "Prognostic Value of Tumour Associated Antigen Immunoreactivity and Apoptosis in Cerebral Glioblastomas: An Analysis of 168 Cases,” Journal of Clinical Pathology, Vol. 52, No. 8, 1999, pp. 574-580. doi:10.1136/jcp.52.8.574

[37] X. Muracciole, S. Romain, H. Dufour, J. Palmari, O. Chinot, L. Ouafik, F. Grisoli, D. F. Branger and P. M. Martin, "PAI-1 and EGFR Expression in Adult Glioma Tumors: Toward a Molecular Prognostic Classification," International Journal of Radiation Oncology, Biology, Physics, Vol. 52, No. 3, 2002, pp. 592-598. doi:10.1016/S0360-3016(01)02699-2

[38] E. W. Newcomb, H. Cohen, S. R. Lee, S. K. Bhalla, J. Bloom, R. L. Hayes and D. C. Miller, "Survival of Patients with Glioblastoma Multiforme Is Not Influenced by Altered Expression of p16, p53, EGFR, MDM2 or Bcl-2 Genes,” Brain Pathology, Vol. 8, No. 4, 1998, pp. 655667. doi:10.1111/j.1750-3639.1998.tb00191.x

[39] T. J. Pigott, D. K. Robson, J. Palmer and L. M. Ward, "Expression of Epidermal Growth Factor Receptor in Human Glioblastoma Multiforme,” British Journal of 
Neurosurgery, Vol. 7, No. 3, 1993, pp. 261-265. doi:10.3109/02688699309023808

[40] T. Saito, M. T. Arifin, S. Hama, Y. Kajiwara, K. Sugiyama, F. Yamasaki, T. Hidaka, K. Arita and K. Kurisu, "Survivin Subcellular Localization in High-Grade Astrocytomas: Simultaneous Expression in both Nucleus and Cytoplasm Is Negative Prognostic Marker," Journal of Neuro-Oncology, Vol. 82, No. 2, 2007, pp. 193-198. doi:10.1007/s11060-006-9267-1

[41] C. Sarkar, S. Sinha, M. C. Sharma, R. Kumar and V. S. Mehta, "Supratentorial Glioblastoma in Adults: Identification of Subsets and Their Clinical Correlation," Brain Tumor Pathology, Vol. 21, No. 1, 2004, pp. 7-12. doi:10.1007/BF02482170

[42] U. Schlegel, J. Neumann, D. Kindermann, H. K. Wolf, A. Baumann, F. Forster and R. Fimmers, "Prognostic Relevance of Transforming Genes," Recent Results in Cancer Research, Vol. 135, 1994, pp. 43-53. doi:10.1007/978-3-642-85039-4_6

[43] A. M. Stark, H. H. Hugo, P. Witzel, Z. Mihajlovic and H. M. Mehdorn, "Age-Related Expression of p53, Mdm2, EGFR and Msh2 in Glioblastoma Multiforme," Zentralblatt fur Neurochirurgie, Vol. 64, No. 1, 2003, pp. 30-36. doi:10.1055/s-2003-37149

[44] A. Tortosa, N. Vinolas, S. Villa, E. Verger, J. M. Gil, M. Brell, L. Caral, T. Pujol, J. J. Acebes, T. Ribalta, I. Ferrer and F. Graus, "Prognostic Implication of Clinical, Radiologic, and Pathologic Features in Patients with Anaplastic Gliomas," Cancer, Vol. 97, No. 4, 2003, pp. 10631071. doi:10.1002/cncr.11120

[45] S. Umesh, A. Tandon, V. Santosh, B. Anandh, S. Sampath, B. A. Chandramouli and V. R. S. Kolluri, "Clinical and Immunohistochemical Prognostic Factors in Adult Glioblastoma Patients,” Clinical Neuropathology, Vol. 28, No. 5, 2009, pp. 362-372.

[46] M. Varela, S. M. Ranuncolo, A. Morand, J. Lastiri, E. B. De Kier Joffe, L. I. Puricelli and M. G. Pallotta, "EGF-R and PDGF-R, but Not Bcl-2, Overexpression Predict Overall Survival in Patients with Low-Grade Astrocytomas,” Journal of Surgical Oncology, Vol. 86, No. 1, 2004, pp. 34-40. doi:10.1002/jso.20036

[47] M. Wrensch, J. K. Wiencke, J. Wiemels, R. Miike, J. Patoka, M. Moghadassi, A. McMillan, K. T. Kelsey, K. Aldape, K. R. Lamborn, A. T. Parsa, J. D. Sison and M. D. Prados, "Serum IgE, Tumor Epidermal Growth Factor Receptor Expression, and Inherited Polymorphisms Associated with Glioma Survival," Cancer Research, Vol. 66, No. 8, 2006, pp. 4531-4541. doi:10.1158/0008-5472.CAN-05-4032

[48] A. Zhu, J. Shaeffer, S. Leslie, P. Kolm and A. M. ElMahdi, "Epidermal Growth Factor Receptor: An Independent Predictor of Survival in Astrocytic Tumors Given Definitive Irradiation," International Journal of Radiation Oncology, Biology, Physics, Vol. 34, No. 4, 1996, pp. 809-815. doi:10.1016/0360-3016(95)02184-1

[49] C. E. Pelloski, K. V. Ballman, A. F. Furth, L. Zhang, E. Lin, E. P. Sulman, K. Bhat, J. M. McDonald, W. K. Yung, H. Colman, S. Y. Woo, A. B. Heimberger, D. Suki, M. D. Prados, S. M. Chang, F. G. Barker II, J. C. Buckner, C. D.
James and K. Aldape, "Epidermal Growth Factor Receptor Variant III Status Defines Clinically Distinct Subtypes of Glioblastoma,” Journal of Clinical Oncology, Vol. 25, No. 16, 2007, pp. 2288-2294. doi:10.1200/JCO.2006.08.0705

[50] S. H. Bigner, P. C. Burger, A. J. Wong, M. H. Werner, S. R. Hamilton, L. H. Muhlbaier, B. Vogelstein and D. D. Bigner, "Gene Amplification in Malignant Human Gliomas: Clinical and Histopathologic Aspects,” Journal of Neuropathology and Experimental Neurology, Vol. 47, No. 3, 1988, pp. 191-205. doi:10.1097/00005072-198805000-00001

[51] E. Galanis, J. Buckner, D. Kimmel, R. Jenkins, B. Alderete, J. O’Fallon, C. H. Wang, B. W. Scheithauer and C. D. James, "Gene Amplification as a Prognostic Factor in Primary and Secondary High-Grade Malignant Gliomas,” International Journal of Oncology, Vol. 13, No. 4, 1998, pp. 717-724.

[52] C. Ang, M. C. Guiot, A. V. Ramanakumar, D. Roberge and P. Kavan, "Clinical Significance of Molecular Biomarkers in Glioblastoma," Canadian Journal of Neurological Sciences, Vol. 37, No. 5, 2010, pp. 625-630.

[53] L. M. Backlund, B. R. Nilsson, H. M. Goike, E. E. Schmidt, L. Liu, K. Ichimura and V. P. Collins, "Short Postoperative Survival for Glioblastoma Patients with a Dysfunctional Rb1 Pathway in Combination with No Wild-Type PTEN,” Clinical Cancer Research, Vol. 9, No. 11, 2003, pp. 4151-4158.

[54] S. Leenstra, N. T. Oskam, E. H. Bijleveld, D. A. Bosch, D. Troost and T. J. Hulsebos, "Genetic Sub-Types of Human Malignant Astrocytoma Correlate with Survival," International Journal of Cancer, Vol. 79, No. 2, 1998, pp. 159-165.

doi:10.1002/(SICI)1097-0215(19980417)79:2<159::AID$\underline{\mathrm{IJC} 11>3.0 . \mathrm{CO} ; 2-5}$

[55] H. Ohgaki, P. Dessen, B. Jourde, S. Horstmann, T. Nishikawa, P. L. Di Patre, C. Burkhard, D. Schuler, N. M. Probst-Hensch, P. C. Maiorka, N. Baeza, P. Pisani, Y. Yonekawa, M. G. Yasargil, U. M. Lutolf and P. Kleihues, "Genetic Pathways to Glioblastoma: A Population-Based Study," Cancer Research, Vol. 64, No. 19, 2004, pp. 6892-6899. doi:10.1158/0008-5472.CAN-04-1337

[56] A. L. Quan, G. H. Barnett, S. Y. Lee, M. A. Vogelbaum, S. A. Toms, S. M. Staugaitis, R. A. Prayson, D. M. Peereboom, G. H. Stevens, B. H. Cohen and J. H. Suh, "Epidermal Growth Factor Receptor Amplification Does Not Have Prognostic Significance in Patients with Glioblastoma Multiforme,” International Journal of Radiation Oncology, Biology, Physics, Vol. 63, No. 3, 2005, pp. 695-703. doi:10.1016/j.jjrobp.2005.03.051

[57] M. Weller, J. Felsberg, C. Hartmann, H. Berger, J. P. Steinbach, J. Schramm, M. Westphal, G. Schackert, M. Simon, J. C. Tonn, O. Heese, D. Krex, G. Nikkhah, T. Pietsch, O. Wiestler, G. Reifenberger, A. von Deimling and M. Loeffler, "Molecular Predictors of ProgressionFree and Overall Survival in Patients with Newly Diagnosed Glioblastoma: A Prospective Translational Study of the German Glioma Network," Journal of Clinical Oncology, Vol. 27, No. 34, 2009, pp. 5743-5750. 


\section{doi:10.1200/JCO.2009.23.0805}

[58] M. Jansen, S. Yip and D. N. Louis, "Molecular Pathology in Adult Gliomas: Diagnostic, Prognostic, and Predictive Markers,” Lancet Neurol, Vol. 9, No. 7, 2010, pp. 717726. doi:10.1016/S1474-4422(10)70105-8

[59] A. von Deimling, K. von Ammon, D. Schoenfeld, O. D. Wiestler, B. R. Seizinger and D. N. Louis, "Subsets of Glioblastoma Multiforme Defined by Molecular Genetic Analysis,” Brain Pathology, Vol. 3, No. 1, 1993, pp. 19-26. doi:10.1111/j.1750-3639.1993.tb00721.x

[60] S. Gulati, B. Ytterhus, U. S. Granli, M. Gulati, S. Lydersen and S. H. Torp, "Overexpression of c-erbB2 Is a Negative Prognostic Factor in Anaplastic Astrocytomas,” Diagnostic Pathology, Vol. 5, 2010, p. 18. doi:10.1186/1746-1596-5-18

[61] S. H. Torp, S. Gulati, E. Johannessen and A. Dalen, “Coexpression of c-erbB 1-4 Receptor Proteins in Human Glioblastomas. An Immunohistochemical Study," Journal of Experimental and Clinical Cancer Research, Vol. 26, No. 3, 2007, pp. 353-359.

[62] S. H. Torp, E. Helseth, A. Dalen and G. Unsgaard, "Epidermal Growth Factor Receptor Expression in Human Gliomas,” Cancer Immunology, Immunotherapy, Vol. 33, No. 1, 1991, pp. 61-64. doi:10.1007/BF01742530

[63] M. H. Werner, L. B. Nanney, C. M. Stoscheck and L. E. King, "Localization of Immunoreactive Epidermal Growth Factor Receptors in Human Nervous System," Journal of Histochemistry and Cytochemistry, Vol. 36, No. 1, 1988, pp. 81-86. doi:10.1177/36.1.3275713

[64] S. Robel, B. Berninger and M. Gotz, "The Stem Cell Potential of Glia: Lessons from Reactive Gliosis,” Nature Reviews Neuroscience, Vol. 12, No. 2, 2011, pp. 88-104. doi:10.1038/nrn2978

[65] F. Burel-Vandenbos, M. Benchetrit, C. Miquel, D. Fontaine, R. Auvergne, C. Lebrun-Frenay, N. Cardot-Leccia, J. F. Michiels, V. Paquis-Flucklinger and T. Virolle, "EGFR Immunolabeling Pattern May Discriminate Low-
Grade Gliomas from Gliosis,” Journal of Neuro- Oncology, Vol. 102, No. 2, 2011, pp. 171-178. doi:10.1007/s11060-010-0308-4

[66] K. S. Yoon, M. C. Lee, S. S. Kang, J. H. Kim, S. Jung, Y. J. Kim, J. H. Lee, K. Y. Ahn, J. S. Lee and J. Y. Cheon, "p53 Mutation and Epidermal Growth Factor Receptor Overexpression in Glioblastoma," Journal of Korean Medical Science, Vol. 16, No. 4, 2001, pp. 481-488.

[67] H. K. Gan, A. H. Kaye and R. B. Luwor, "The EGFRvIII Variant in Glioblastoma Multiforme,” Journal of Clinical Neuroscience, Vol. 16, No. 6, 2009, pp. 748-754. doi:10.1016/j.jocn.2008.12.005

[68] I. K. Mellinghoff, M. Y. Wang, I. Vivanco, D. A. Haas-Kogan, S. Zhu, E. Q. Dia, K. V. Lu, K. Yoshimoto, J. H. Huang, D. J. Chute, B. L. Riggs, S. Horvath, L. M. Liau, W. K. Cavenee, P. N. Rao, R. Beroukhim, T. C. Peck, J. C. Lee, W. R. Sellers, D. Stokoe, M. Prados, T. F. Cloughesy, C. L. Sawyers and P. S. Mischel, "Molecular Determinants of the Response of Glioblastomas to EGFR Kinase Inhibitors," New England Journal of Medicine, Vol. 353, No. 19, 2005, pp. 2012-2024. doi:10.1056/NEJMoa051918

[69] C. J. Wikstrand, R. E. McLendon, A. H. Friedman and D. D. Bigner, "Cell Surface Localization and Density of the Tumor-Associated Variant of the Epidermal Growth Factor Receptor, EGFRvIII,” Cancer Research, Vol. 57, No. 18, 1997, pp. 4130-4140.

[70] L. Ohman, L. Gedda, G. Hesselager, R. Larsson, M. Nister, T. Stigbrand, K. Wester and J. Carlsson, "A New Antibody Recognizing the vIII Mutation of Human Epidermal Growth Factor Receptor,” Tumour Biology, Vol. 23, No. 2, 2002, pp. 61-69. doi:10.1159/000059704

[71] Y. H. Zhou, K. R. Hess, V. R. Raj, L. Yu, L. Liu, A. W. Yung and M. E. Linskey, "Establishment of Prognostic Models for Astrocytic and Oligodendroglial Brain Tumors with Standardized Quantification of Marker Gene Expression and Clinical Variables," Biomark Insights, Vol. 5, 2010, pp. 153-168. doi:10.4137/BMI.S6167 